We have thus in this species a unique example of an European butterfly, which mimics the dead leaf as perfectly, and possibly even not worse, than several celebrated tropical species.

\title{
SOME INSECTS OF THE HUDSONIAN ZONE IN NEW MEXICO.-IV.
}

\section{HYMENOPTERA.}

(Part)

BY WILLIAM H. ASHMEAD.

Family Crabronidae.

(1) Stenocrabro cinctitarsis, new species.

8.- Length $6.5 \mathrm{~mm}$. Black, shining; the tibial spurs, the extreme apex of the first joint of the anterior tarsi and joints 2 and 3 entirely, and joints $\mathrm{I}$ to 3 of middle tarsi, yellowish-white. The clypeus at apex medially is subproduced and clothed with a dense silvery pubescence; the mandibles and the mesopectus with sparse silvery hairs. The head is quadrate, smooth above, but anteriorly it is sparsely, minutely punctate and with a median grooved line; the eyes are large and converge anteriorly; the ocelli are arranged in a triangle, the space between the margin of the eye and the lateral ocelli being greater than the space between them. Mandibles black, bidentate. The pronotum is not short and has a deep transverse impression above, the hind margin having a delicate median notch which conforms to a delicate median grooved line on the anterior half of the mesonotum; both of these sclerites are smooth and shining, although with a high power lens one can detect sparse, microscopic punctures scattered over the surface. The metathorax above is smooth, polished, with a broad median groove and an oblong area on each side of the groove; the posterior face of the metathorax is transversely regulose, the pleura striate. The wings are hyaline, with a faint fuscous tinge, the stigma and veins being brown, the stigma and costal vein dark brown; the recurrent nervure unites with the cubital cell just beyond its middle. The abdomen is a little longer than the head and thorax united, subclavate, smooth and shining, but with a high power lens, exhibits, particularly on the second and third dorsal segments and the base of the third, very fine, delicate, transverse aciculations.

Type-Cat. No. 5349, U. S. N. M.

Habitat. - Top of range between the Sapello and Pecos Rivers at an altitude of about I rooo feet. One $\delta$ specimen.

\section{Family Pompilidae.}

(2) Ceropales fraterna Smith.

Prof. Cockerell has taken one $q$ specimen. It is a species widely spread over Canada and the United States.

\section{Family Eumenidae.}

(3) Ancistrocerus sexcingulatus, new species.

8.- Length $8 \mathrm{~mm}$. Black with the head and thorax rather coarsely punctate; a broad apical band on dorsal abdominal segments $I$ to 6 , a band at apex of ventral segments 2 and 3 and a spot at hind angles of 4 and 5 , the mandibles except at apex, the clypeus entirely, a short orbital line opposite the antennae, a spot between the antennae, a dot on temples back of the eyes, the scape beneath and two or three of the following antennal joints 
beneath, a transverse band on the anterior margin of the pronotum, two spots on the tegulae, two dots on the scutellum and the legs from the apices of the femora, lemon-yellow; flagellum beneath and including the hook and the penultimate joint fulvous.

Type.-Cat. No. $535^{\circ}$, U. S. N. M.

Habitat.- New Mexico.

Described from I $\delta$ specimen. The species comes evidently nearest to $A$. bustamenti Saussure, described from Mexico and known only in the female sex.

\section{Family Formicidae.}

(4) Formica neorufibarbis Emery.

Two $q$ specimens. (Determined by Mr. Theo. Pergande.)

Family Tenthredinidae.

(5) Tenthredo erythromeraProvancher. One $\$$ specimen. Occurs in British Columbia and Alaska.

(6) Labidia originalis Norton.

One $₹$ specimen. Recorded from Colorado, British Columbia, Vancouver Island.

\section{LEPIDOP'TEKA RHOPALOCERA.}

BY T. D. A. COCKERELL.

\section{Pyrameis cardui $L$.}

Vanessa milbertii subsp. subpallida Ckll.

Argynnis eurynome Edw. Very abundant.

Argynnis electa Edw., det. Skin- ner. Only one taken; it is common in the same region at lower altitudes, where eurynome is not found.

Brenthis helena Edw, det. Skinner. Abundant. Dr. Skinner would not separate Brenthis from Argynnis, but they seem to me sufficiently distinct.

Erebia epipsodea Butler.

Coenonympha ochracea Edw. Common; forms with only one pupilled ocellus on under side of secondaries.

Chrysophanus helloides Bdv. Common.

Lycæna rustica Edw. Common; one is smaller than usual, with the ground-color of under side of secondaries quite dark, thus approaching $L$. aquilo.

Colias eurytheme Bdv.

Colias scudderi Reak. var. flavotincta n. var; $q$ delicate pale yellow, $\delta$ normal. The $q$ is figured (fig. 5) on Edwards' plate in Butt. N. A. Several seen ; my wife took a pair.

Parnassius smintheus Dbl. \& Hew. One $\delta$ taken by my wife; expanse 63 $\mathrm{mm}$. This is certainly smintheus, considering the locality, but it is unusually dark, and marked almost exactly as $P$. clodius var. baldur, figured (pl. 39, fig. 7 ) in Holland's Butterfly Book.

Pamphila comma nevada Scudd. det. Skinner. Common, both sexes taken.

Pyrgus centaureae Ramb., det. Skinner. $\delta$. 

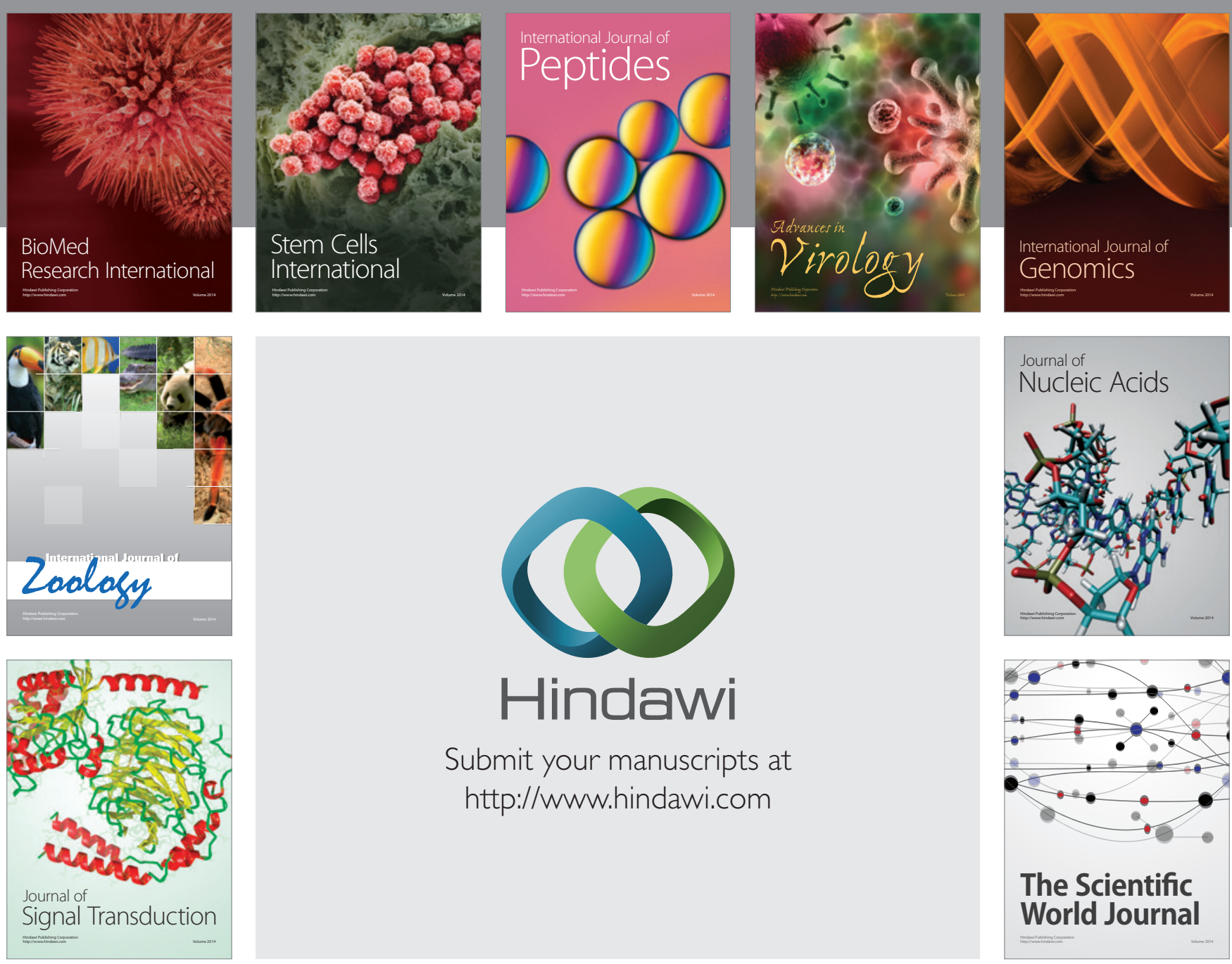

Submit your manuscripts at

http://www.hindawi.com
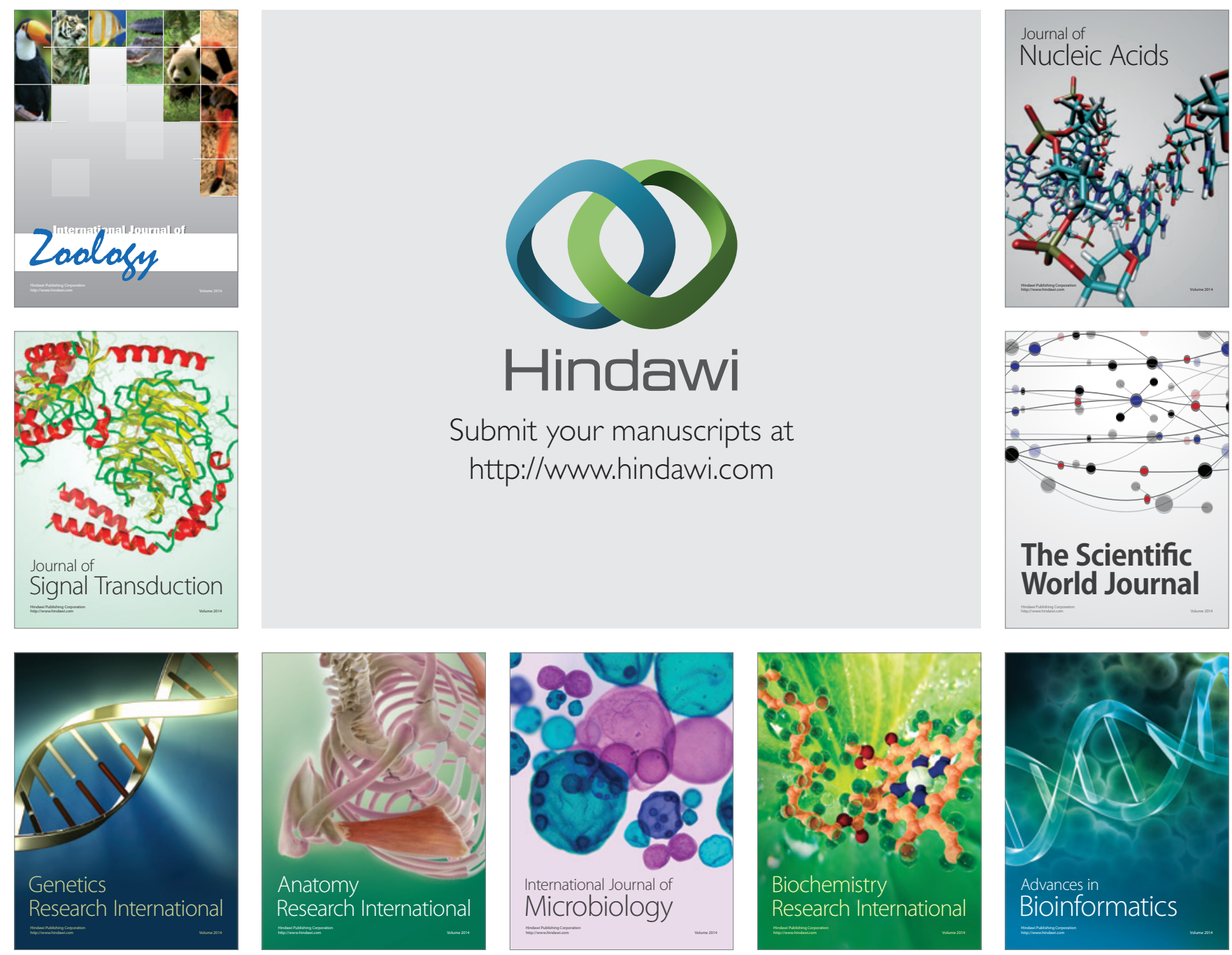

The Scientific World Journal
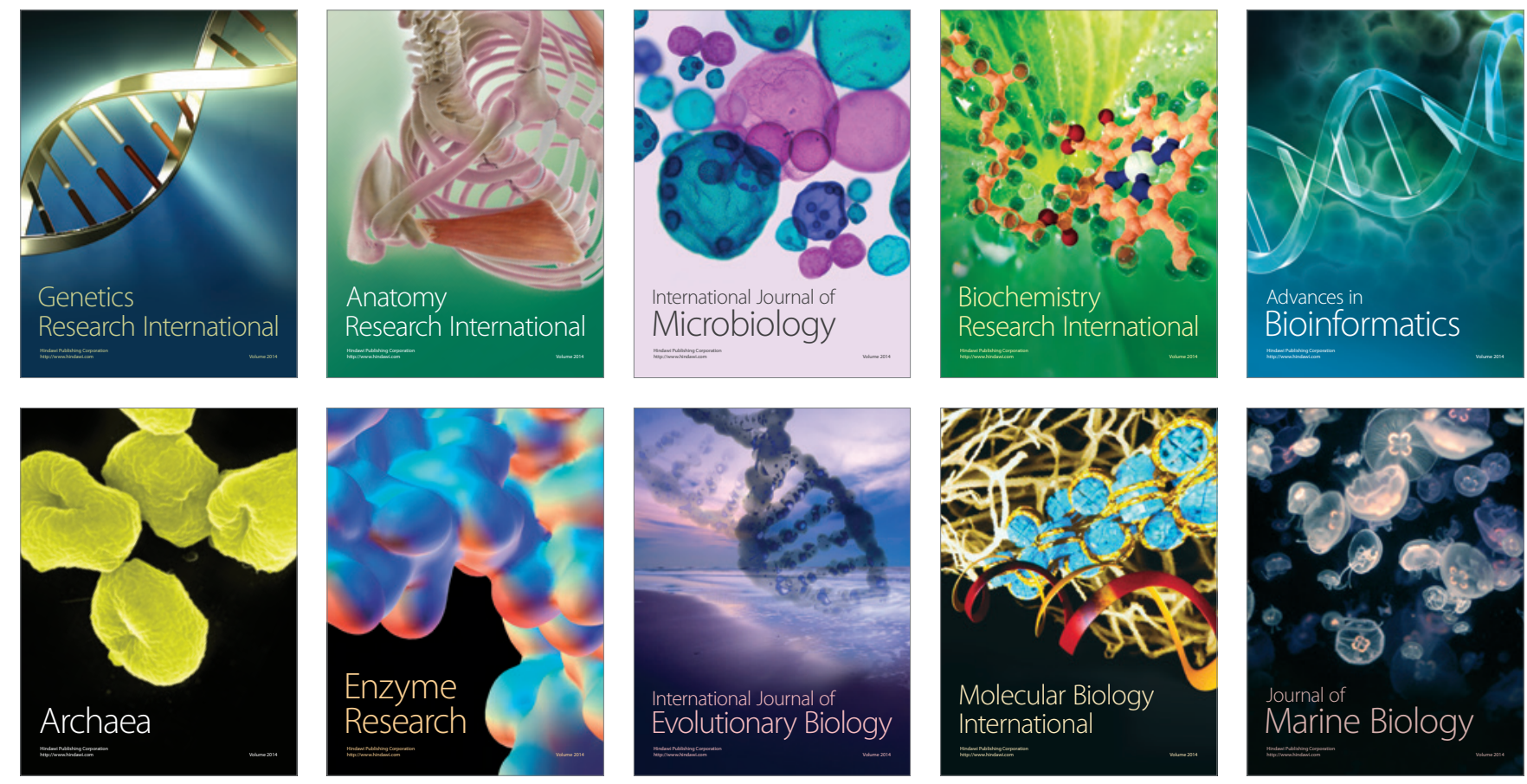